POLITEKNIK NEGERI NUSA UTARA

\title{
PEMAHAMAN DAN PERILAKU PENCEGAHAN CORONAVIRUS DESEASE 2019 DI KALANGAN CIVITAS AKADEMIKA POLITEKNIK NEGERI NUSA UTARA PADA MASA NEW NORMAL TAHUN 2020
}

\author{
UNDERSTANDING AND PRATICE OF NUSA UTARA STATE POLITECHNIC PEOPLE ABOUT \\ CORONAVIRUS DESEASE 2019 IN NEW NORMAL ERA 2020
}

\author{
Chandrayani Simanjorang, Gracia Tooy, Grace Wuaten, Nancy Pangandaheng \\ Program Studi Keperawatan, Jurusan Kesehatan,Politeknik Negeri Nusa Utara \\ Email: simanjorangyani@gmail.com
}

\begin{abstract}
Abstrak: Dalam rangka mencegah terjadinya penularan COVID-19 dan berjalannya roda perekonomian di Indonesia, pemerintah saat ini memberlakukan kebijakan new normal. Sehingga penekanan tingkat penularan sangat bergantung kepada pemahaman dan praktik pencegahan masyarakat terkait COVID-19. Tujuan penelitian ini untuk mengetahui informasi tentang pemahaman dan perilaku civitas akademika (dosen, mahasiswa, dan tenaga kependidikan) Politeknik Negeri Nusa Utara terkait COVID-19 dan pencegahannya. Desain penelitian berupa cross-sectional dengan waktu pengambilan sampel 17-30 September 2020 secara online. Teknik pengambilan sampel berupa purposive sampling dengan kriteria inklusi adalah civitas akademika Politeknik Negeri Nusa Utara, usia $\geq 16$ tahun, dan bersedia menjadi partisipan. Partisipan yang bekerja di bidang kesehatan sebagai kriteria eksklusi. Seluruh partisipan diminta kesediannya dengan memberikan inform consent kemudian jika bersedia akan mengisi kuesioner secara online. Kuesioner disusun berdasarkan informasi yang tersedia dalam buku pedoman kementrian kesehatan tentang COVID-19 dan merupakan modifikasi dari kuesioner penelitan sebelumnya. Pertanyaan pada kuesioner berupa pertanyaan terbuka, tertutup, dan berskala. Pertanyaan bertujuan untuk mengevaluasi pemahaman tentang virology, gejala, faktor risiko, pencegahan, dan penanganan gejala. Setiap jawaban benar diberikan nilai 10 pada pemahaman. Partisipan yang memiliki skor lebih dari 60 dikategorikan berpemahaman baik. Pada skala perilaku, skor 40-50 masuk kategori good practice dan $<40$ sebagai kategori poor practice. Dari 127 responden terdapat 34,6\% memiliki pemahaman yang baik dan $65,4 \%$ memiliki pemahaman yang kurang terkait COVID-19. Sementara untuk praktik pencegahan COVID-19, 93,7\% berperilaku baik dan 6,3\% berperilaku kurang. Kesimpulannya adalah Mayoritas responden memiliki pemahaman yang kurang tentang penyebab, gejala, dan pencegahan COVID-19 khususnya mencuci tangan dengan sabun. Terdapat perbedaan proporsi tingkat pemahaman berdasarkan tingkat pendidikan $(\mathrm{p}<0.05)$.
\end{abstract}

Kata_kunci: COVID-19, pemahaman, praktik, Politeknik Negeri Nusa Utara

Abstract: To prevent the spread of COVID-19 and the economy in Indonesia has to run, the government is currently implementing a new normal policy. So that the emphasis on the level of transmission really depends on the understanding and practices of the community related to COVID-19. The purpose of this study was to find out information about the knowledge and practice of Nusa Utara State Polytechnic people about COVID-19 and it is prevention. Cross-sectional design was chosen as the research design with online sampling time on 17-30 September 2020. The sampling technique was purposive sampling with inclusion criteria were people who live in Sate Polytechnic of Nusa Utara with the age $\geq 16$ years old. All participants were asked to provide the informed consent, which if they agreed they would fill out online questionnaires. The questionnaire was compiled based on information available in the Ministry of Health's guidebook on COVID-19 and it was the modification of the previous research questionnaire. The questions on the questionnaire were open, close, and scaled questions. Questions aimed to evaluate the knowledge about virology, symptoms, risk factors, preventions, and management of symptoms. Each correct answer was assigned a score of 10 on knowledge. Participants who had a score of more than 60 


\begin{abstract}
were categorized as the ones who had good knowledge. In practice scale, core of 40 - 50 falls in the good practice category and score $<40$ fall in the category of poor practice. The research design was crosssectional with online data-based from 17-28 September 2020. There were 127 respondents, $34.6 \%$ had a good knowledge and $65.4 \%$ had a poor knowledge of COVID-19. Meanwhile, for the practice of preventing COVID-19, 93.7\% had good behavior and 6.3\% had poor behavior. The conclusion is the majority of respondents had insufficient knowledge about causative factor, symptoms and prevention of COVID-19 such as handwashing. There were difference in the proportion of knowledge levels based on education level $(p<0.05)$.
\end{abstract}

Keywords: COVID-19, understanding, practice, State Polytechnic of Nusa Utara

\section{PENDAHULUAN}

Corona Virus Desease 2019 (COVID-19) dinyatakan sebagai pandemik global oleh WHO. Menurut laporan WHO, terdapat 30.675.675 kasus positif COVID-19 dengan tingkat kematian 3\% pada 20 September 2020. (WHO, 2020). Di waktu yang sama di Indonesia kasus COVID-19 mencapai 244.676 kasus dengan tingkat kematian $4 \%$. Kasus COVID-19 di Indonesia besaral dari semua provinsi termasuk Sulawesi Utara. Tercatat 4.295 kasus berasal dari Sulawesi Utara dengan tingkat kematian 4\%. (BNPB, 2020).

Indonesia menjadi salah satu episenter penyebaran COVID-19. Untuk mencegah penularan di masyarakat pemerintah menerapkan Physical Distancing dengan penetapan kebijakan Pembatasan Sosial Berskala Besar (PSBB) sejak April 2020. (Presiden RI, 2020). Kemudian pada akhir Juni kebijakan PSBB dicabut digantikan dengan "new normal" yang memungkinkan masyarakat dapat beraktivitas di luar rumah dengan menetapkan protokol kesehatan. ${ }^{4}$ Pada periode new normal ini, penekanan laju insiden COVID-19 sangat bergantung kepada disiplin masyarakat dalam melaksanakan protokol kesehatan. Kepatuhan masyarakat dalam menerapkan protokol kesehatan sangat dipengaruhi oleh pemahaman, sikap, dan perilaku masyarakat terkait COVID-19. (Zong et al., 2020).

Pada awal pandemic di Indonesia, tingkat pemahaman terkait COVID-19 di kalangan anak muda masih kurang. (Halim et al., 2020). Namun hasil ini tidak mewakili masyarakat Indonesia dari seluruh provinsi khususnya Indonesia bagian tengah dan timur. Masyarakat usia muda lebih memilih akses informasi melalui media social daripada situs yang disediakan oleh pemerintah. (Halim et al., 2020). Sehingga dibutuhkan penelitian lebih lanjut. Sulawesi Utara sebagai salah satu provinsi terdampak COVID-19. Politeknik Negeri Nusa Utara sebagai salah satu pendidikan tinggi yang ada di Sulawesi Utara memiliki peran penting dalam membawa perubahan di masyarakat termasuk didalamnya tentang pencegahan COVID-19. Oleh karena itu, peneliti memilih institusi ini sebagai tempat dilakukannya penelitian. Dengan harapan temuan penelitian bersifat spesifik lokal yang memungkinkan intervensi promosi kesehatan lebih efektif. Penelitian ini bertujuan untuk mengetahui tingkat pemahaman dan perilaku civitas akademika Politeknik Negeri Nusa Utara (dosen, mahasiswa, dan tenaga kependidikan) terkait covid-19 di masa new normal tahun 2020.

\section{METODE PENELITIAN}

Desain penelitian berupa cross-sectional dengan waktu pengumpulan data 17-28 September 2020. Populasi dalam penelitian ini adalah seluruh civitas akademika (tenaga pendidik, tenaga kependidikan, dan mahasiswa) Politeknik Negeri Nusa Utara. Analisis statistik menggunakan SPSS 20.0. Data deskriptif (kontinyu) akan 
disajikan dalam bentuk angka absolut dan variabel kategorik dalam bentuk persentase. Analasis untuk bivariat menggunakan chi-square dengan $\mathrm{P}$-value <0.05 sebagai standar signifikansi. Sampel penelitian dipilih secara purposive sampling dengan kriteria inklusi dosen, mahasiswa, dan tenaga kependidikan Politeknik Negeri Nusa Utara, usia $\geq 16$ tahun, dan bersedia menjadi partisipan dan mengisi kuesioner penelitian. Seluruh partisipan diminta kesediannya dengan memberikan inform consent kemudian jika bersedia akan mengisi kuesioner secara online.

Kuesioner disusun berdasarkan informasi yang tersedia dalam buku pedoman kementrian kesehatan tentang covid-19 dan merupakan modifikasi dari kuesioner penelitan tim Universitas Pelita Harapan Jakarta yang sudah diuji. Kuesioner terdiri dari 3 bagian yaitu karakteristik demografi, tingkat pemahaman dan perilaku. Variabel demografi diantaranya gender, usia, dan pendidikan. Kuesioner tentang pepemahaman dan perilaku dikembangkan berdasarkan pedoman dari kementrian kesehatan serta modifikasi dari kuesioner penelitian sebelumnya. (Kementrian Kesehatan, 2020; Halim et al., 2020). Pemahaman terdiri dari 10 pertanyaan yaitu 4 pertanyaan tentang gejala klinis dan penyebab COVID-19 (K1-K4), 4 pertanyaan tentang pencegahan (K5-K7), dan 3 pertanyaan tentang kontrol penularan oleh pemerintah (K8K10). Jawaban kuesioner berupa benar/dalah/tidak tahu. Setiap jawaban benar diberi nilai 10 points, dimana jika nilai total $\geq 60$ dikategorikan sebagai good knowledge dan $<$ 60 sebagai poor knowledge. Sementara kuesioner untuk menilai perilaku pencegahan COVID-19 menggunakan 10 pertanyaan dimana jawaban dari setiap pertanyaan diberikan skor 1-5. Skor $1=$ Tidak pernah, $2=$ Jarang , $3=$ Kadang-kadang, 4 = Sering, 5 = Selalu. Skor 40-50 masuk kategori good practice dan $<40$ sebagai kategori poor practice.

\section{HASIL DAN PEMBAHASAN}

Jumlah total sampel dalam penelitian ini adalah 127 partisipan, dimana mayoritas responden adalah perempuan (78\%), kelompok usia 16-29 tahun (92\%), dengan tingkat pendidikan paling banyak merupakan pendidikan menengah (91\%). [Tabel 1]. Tingkat pemahaman mayoritas responden berada pada kategori kurang (65.4\%). [Tabel 2]. Berdasarkan grafik 1 proporsi kurangnya pemahaman paling banyak pada pertanyaan nomor 1 (Q1) yaitu tentang penyebab COVID-19, pertanyaan nomor 5 (Q5) yaitu pemahaman tentang gejala, pertanyaan nomor 3 (Q3) yaitu pemahaman tentang istilah "new normal", pertanyaan nomor 9 (Q9) tentang pencegahan dengan mencuci tangan, dan pemahaman tentang situs resmi pemerintah terkait COVID-19 pada pertanyaan 10 (Q10).

Tabel 3 menunjukkan bahwa mayoritas responden berperilaku baik terkait pencegahan COVID-19. Namun beberapa praktik pencegahan dilakukan dengan jarang atau kadang-kadang oleh mayoritas responden yaitu terkait mencuci tangan dengan sabun selama 20 detik (QP1), akses informasi (QP3 \& QP10), dan tentang menghindari kerumunan (QP6).

\section{POLITEKNIK NEGERI NUSA UTARA}


Tabel 1. Karakteristik Demografi Responden Penekitian

\begin{tabular}{lc}
\hline Karakteristik & Frekuensi (\%) \\
\hline Jenis kelamin & $28(22)$ \\
Laki-laki & $99(78)$ \\
Perempuan & \\
Kelompok usia & $117(92)$ \\
$16-29$ & $10(8)$ \\
30-50 & $115(91)$ \\
Pendidikan terakhir & $12(8)$ \\
Pendidikan menengah & \\
Pendidikan tinggi
\end{tabular}

Tabel 2. Gambaran Responden Menurut Tingkat Pemahaman

\begin{tabular}{lcc}
\hline Tingkat Pemahaman & N & \% \\
\hline Baik & 44 & 34.6 \\
Kurang & 83 & 65.4 \\
\hline
\end{tabular}

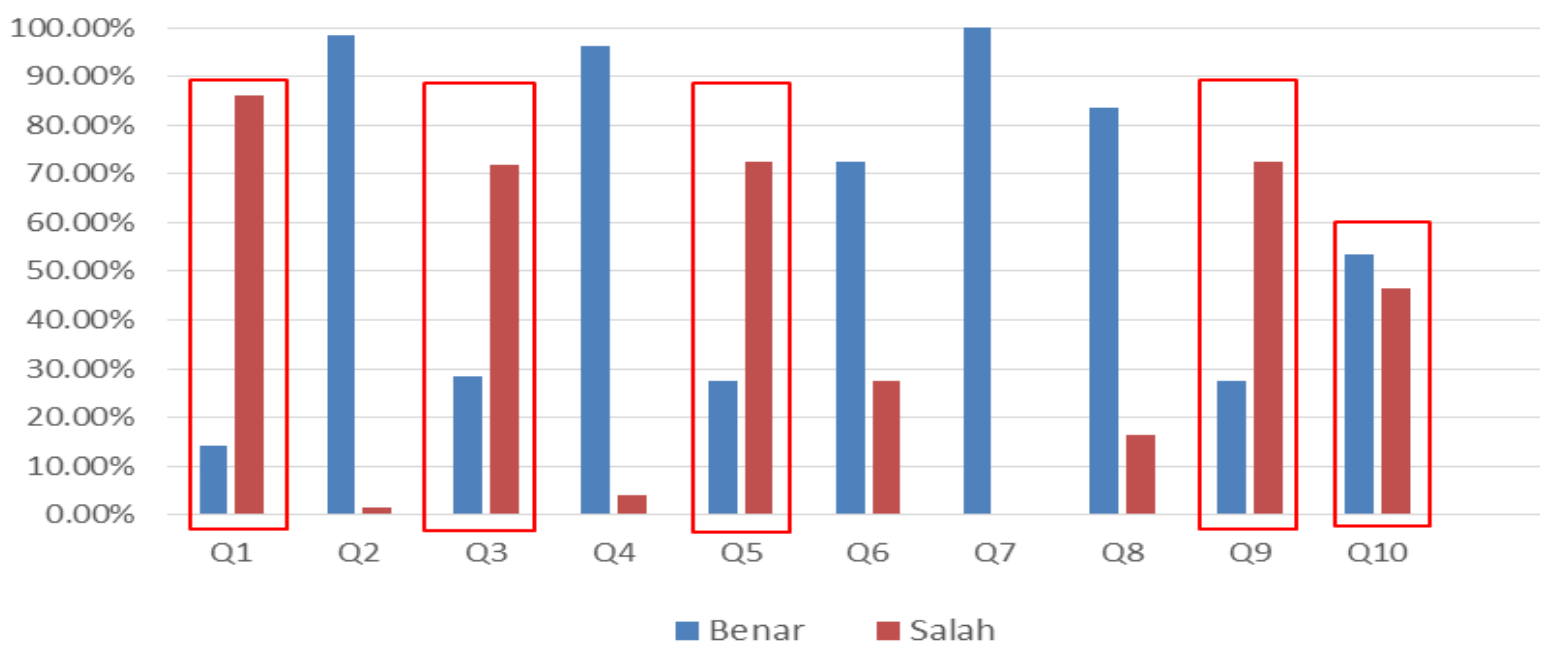

Grafik 1. Distribusi Jawaban Responden Berdasarkan Kuesioner Pemahaman 
Tabel 3. Gambaran Responden Menurut Perilaku Pencegahan COVID-19

\begin{tabular}{lcc}
\hline Perilaku Pencegahan & N & \% \\
\hline Baik & 119 & 93.7 \\
Kurang & 8 & 6.3 \\
\hline
\end{tabular}

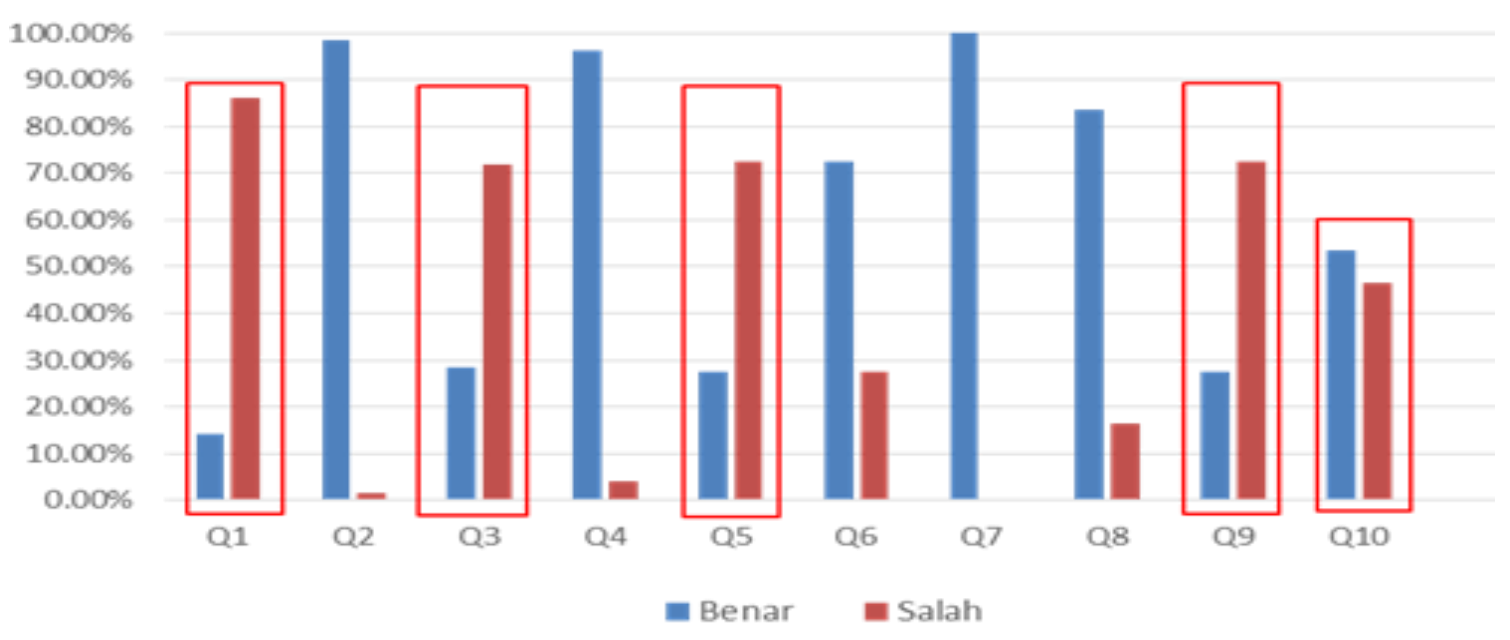

Grafik 2. Distribusi Jawaban Responden Berdasarkan Kuesioner Perilaku

Berdasarkan hasil penelitian ini dapat disimpulkan bahwa pemahaman tentang COVID-19 di kalangan civitas akademika Politeknik Negeri Nusa Utara masih kurang. Khususnya pertanyaan yang berhubungan dengan penyebab, gejala, pencegahan, pengertian new normal, dan akses informasi di situs pemerintah terkait COVID-19. Namun dalam praktik sehari-hari sebagian besar responden melakukan pencegahan dengan menggunakan masker dan jaga jarak. Sejalan dengan penelitian Halim et al pada awal pandemic COVID-19 di Indonesia bahwa mayoritas penduduk muda Indonesia memiliki pemahaman yang kurang tentang mencuci tangan dengan sabun. (Halim et al.,
2020). Berbeda dengan studi yang dilakukan di China hanya kurang dari $5 \%$ penduduk yang masih berkerumun saat pandemic COVID-19. (Zong et al, 2020).

Meskipun sebagian besar responden melakukan cuci tangan dengan sabun namun sebagian besar diantaranya tidak memiliki pemahaman yang benar tentang waktu dan cara mencuci tangan. Perilaku mencuci tangan dengan teratur tanpa memiliki pemahaman yang benar maka akan menyebabkan perilaku yang ada saat ini dapat berubah jika wabah COVID-19 sudah reda. Padahal perilaku mencuci tangan adalah salah satu perilaku hidup sehat yang harus

\section{POLITEKNIK NEGERI NUSA UTARA}


terus menerus dilakukan. Data riskesdas 2013 menunjukkan bahwa hanya $47 \%$ penduduk Indonesia yang melakukan cuci tangan dengan baik dan benar. (Balitbangkes, 2013). Oleh sebab itu edukasi tentang cara mencuci tangan, penyebab, gejala, pengertian new normal di kalanagan sivitas akademika Polnustar sangat direkomendasikan.

Jika mayoritas responden yang memiliki pengetahuan yang kurang terkait pencegahan COVID-19, maka mayoritas perilaku pencegahan yang baik. Hal ini kemungkinan disebabkan adanya kebijakan pemerintah Indonesia yang mengharuskan masyarakat mematuhi protokol kesehatan. Berbeda dengan hasil penelitian di Malaysia dan India pada awal pandemi menemukan bahwa mayoritas responden memiliki pengetahuan dan perilaku yang sama baiknya terkait COVID-19. (Azlan et al., 2020; Dhakar et al., 2020).

\section{KESIMPULAN}

Secara demografi mayoritas responden adalah perempuan, usia 16-19 tahun dan pendidikan menengah. Sebagian besar civitas akademika Politeknik Negeri Nusa Utara memiliki tingkat pemahaman yang kurang terkait COVID-19 khususnya tentang penyebab, gejala, definisi new normal dan pencegahan melalui mencuci tangan dengan sabun. Namun pada kategori perilaku mayoritas responden berperilaku baik dengan melakukan tindakantindakan pencegahan terhadap COVID-19 seperti menggunakan masker, menjaga jarak, dan mencuci tangan dengan sabun. Perlaku yang baik ini dapat disebabkan oleh adanya aturan pemerintah yang mewajibkan masyarakat melaksanakan protokol kesehatan di masa pandemi. Kepatuhan yang baik tanpa disertai pemahaman yang baik dapat menyebabkan perilaku baik tersebut tidak bertahan lama.
Kelemahan penelitian ini adalah kuisioner diisi sendiri oleh responden sehingga jawaban terhadap perilaku pencegahan ada kemungkinan diisi sesuai dengan apa yang responden harapkan ada pada diri mereka. Bukan apa yang sebenarnya mereka rasakan dan lakukan.

\section{SARAN}

Meskipun perilaku atau praktik pencegahan covid19 sudah baik namun pemahaman yang kurang dapat menyebabkan perilaku pencegahan tidak bertahan lama (sustain). Karena kemungkinan ketaatan terhadap protokol kesehatan disebabkan oleh pengaruh lingkungan sekitar maupun tekanan (reinforcement) dari pemangku kebijakan. (Notoadmodjo, 2010). Oleh karena itu perlu edukasi berkelanjutan terkait COVID-19 dan pencegahannya yang diberikan kepada civitas akademika Polnustar khususnya mahasiswa. Kemudian perlu dilakukan penelitian selanjutnya secara kualitatif untuk menggali informasi tentang faktor-faktor penyebab perilaku pencegahan yang baik meskipun tanpa pemahaman yang kurang memadai.

\section{DAFTAR RUJUKAN}

Azlan AA , Hamzah MR, Sern TJ , Ayub SH , Mohamad E. 2020. Public knowledge, attitudes and practices towards COVID-19: A cross-sectional study in Malaysia. Plos One.

Badan Penelitian dan Pengembangan Kesehatan. 2014. Riset Kesehatan Dasar (RISKESDAS) 2013. Lap Nas;1-384.

BNPB Indonesia. 2020. Data Sebaran. Gugus Tugas Percepatan Penanganan COVID-19. Available from: https:// covid19.go.id/. (accessed September 21, 2020).

\section{POLITEKNIK NEGERI NUSA UTARA}


Dkhar SA, Quansar R, Saleem SM, Khan SM. 2020. Knowledge, Attitude, and Practices Related to COVID-19 Pandemic among Social Media Users in J\&K, India. Indian Journal of Public Health, 64 (2): 205-10.

Halim DA, Kurniawan A, Agung FH, Angelina S, Jodhinata C, Wnata S, et al. 2020. Understanding of Young People About COVID-19 During Early Outbreak in Indonesia. 2020; Asia Pacific Journal of Public Health. Available form: https://doi.org/10.1177/1010539520940933

Kementrian Kesehatan RI. 2020. Pedoman Pencegahan dan Pengendalian Corona Virus Desease 2019 (COVID19). Jakarta.

Kompas. 2020. Adaptasi New Normal, Kapolri Cabut Maklumat available form: https: //nasional.kompas.com/read/2020/06/26/12395951/a daptasi-new-normal-kapolri-cabutmaklumat?page=all. $($ accessed September 21, 2020)
Notoadmodjo S. 2010. Promosi Kesehatan Teori dan Aplikasi. Jakarta: Rineka Cipta

Presiden Republik Indonesia. 2020. PP RI Nomor 21 Tahun 2020 tentang Pembatasan Sosial Berskala Besar Dalam Rangka Percepatan Penanganan Corona Virus Disease 2019 (Covid-19). Available from: https://peraturan.bpk.go.id/Home/Details/135059/pp -no-21-tahun-2020. (accessed September 21, 2020)

WHO. 2020. WHO Coronavirus Disease (COVID-19) Dashboard. Available from: https://covid19.who.int/. (accessed September 21, 2020)

Zhong BL, Luo W, Li HM, et al. 2020. Knowledge, attitudes, and practices towards COVID-19 among Chinese residents during the rapid rise period of the COVID-19 outbreak: a quick online cross-sectional survey. Int J Biol Sci, 16:1745-1752. 